\title{
[Strategic] Financial school management in Kurdistan region of Iraq
}

\section{Kameran Noori Abdullah}

Department of English Language, Ministry of Education, Erbil, Kurdistan Region, Iraq Englishhome24@gmail.com

\section{ARTICLE INFO}

\section{Article History:}

Received: 12/10/2020

Accepted: $26 / 11 / 2020$

Published: Winter 2020

\section{Keywords:}

Financial management,

Strategic management, School management, Headmasters, Principals

\section{Doi:}

10.25212/Ifu.qzj.5.4.34

\begin{abstract}
Strategic financial management ability, as one of the key leverage and key drivers of development, is a subject that has always been endorsed by experts and executives; however, it has been long neglected in the domain of education. Considering the importance of this issue in the area of education, this study aimed at investigating the school headmasters' opinions towards this type of management and its implementation in the schools of the Kurdistan region of Iraq. In this respect, 12 high school principals from this context were selected as the participants of this study. The interview was used as the research instrument in this qualitative study. The findings which are elaborated in the results section revealed that the education system had acted very poorly in developing and improving the financial management in Kurdistan, and must try to provide better and appropriate training for the school headmasters and increase the school funding to help school principals remove the problems and difficulties they face in this regard.
\end{abstract}




\section{QALAAI ZANISTSCIENTIFIC JOURNAL \\ A Scientific Quarterly Refereed Journal Issued by Lebanese French University - Erbil, Kurdistan, Iraq \\ Vol. (5), No (4), Winter 2020 \\ ISSN 2518-6566 (Online) - ISSN 2518-6558 (Print)}

\section{INTRODUCTION}

The strategic financial management as defined by Delkhosh and Mousavi (2016), refers to a set of decisions and actions for managing the funds and resources which is the determiner of the organization's long term performance.

Strategic management is influenced by organizational culture and values. In determining this kind of strategy we need to know where we are standing now and where we are heading to. In the educational context for example, in order to act strategically during the process of financial management, we should know to what educational needs our activities are going to respond, what problems they are going to solve, what is the problem solving method, and who is/are going to be affected by what we do.

Strategic management enables the organization to act in a creative and innovative way, instead of passively shaping its future. This way of management also makes the organization take influential activities and consequently helps it to determine its destiny and to control its future.

However, financial management in the domain of education, as defined by Oosthuizen (2003), refers to the money distribution and use of the given funds and school budget in the way of producing and enhancing learner achievement and providing educational services. Financial management in this area is helpful in estimating the educational needs, obtaining money and finances based on these estimated needs, and finally using these finances appropriately and legally to meet these educational needs (Mpolokeng, 2011).

According to Owen (2006), in the case of education system, all school principals are supposed to be familiar with the financial numeracy as an important and essential skill which enables them to set and manage the budget and consequently manage the expenses.

According to Karadag (2015) and Okafor (2012), it has been believed that poor financial management practice leads to the poor performance of the organization, 


\section{QALAAI ZANISTSCIENTIFIC JOURNAL \\ A Scientific Quarterly Refereed Journal Issued by Lebanese French University - Erbil, Kurdistan, Iraq \\ Vol. (5), No (4), Winter 2020 \\ ISSN 2518-6566 (Online) - ISSN 2518-6558 (Print)}

and is the main cause of organization's failure. Considering this issue and the fact that in public schools in the Kurdistan region of Iraq, the financial management is the responsibility of the school principal or headmaster, the question raises that what strategies do these principals adopt to manage the school funds and budgets in the best way and what strategies of financial management do they care and use more. Finding the answers to these questions can be helpful in determining the best strategies for this type of management, with regard to the extent of success or failure of these schools in terms of the students' educational and learning outcomes. Moreover, since knowing about the difficulties one may face in doing something can be helpful in thinking and planning to overcome and eliminate those difficulties, hence the researcher raises the problem that what challenges or difficulties that headmasters may face in implementing financial management in their schools.

Accordingly, the aim of this study is to explore the type of strategies used by school principals in planning financial resources and using the finances for effective financial management in Kurdistan region. This study also focuses on the priorities the participants give to the financial management strategies, and the challenges they face in implementing these strategies.

It has been widely believed that the strategies adopted to manage finances in an organization directly or indirectly affect the development and success of that organization. Therefore, studying these strategies and the challenges in implementing school financial management is important for the impact it has on the educational outcomes.

Moreover, reviewing the previous studies on the issue of strategic financial management in school settings, surprisingly no single study had been observed in the context of Kurdistan region of Iraq, which highlights the significance of the present study.

This study addresses the following research questions: 
(a) What are the most frequent strategies used by high school principals in Iraqi Kurdistan?

(b) What are the challenges and difficulties do high school principals in Iraqi Kurdistan face in the process of school financial management?

\section{Methodology}

\section{Participants}

The population of this study consisted of all high school principals in Erbil City, Kurdistan region of Iraq. Using simple random sampling method, 12 high schools in the Erbil of Kurdistan were selected, and since in this context, the head masters are responsible for managing the school resources and finances, the principals of these six schools were selected as the participants in this study.

\section{Instruments}

A semi-structured interview was used as the research instrument in this study. Hence this study is a qualitative study.

\section{$\underline{\text { Interview }}$}

A semi-structured interview was used as the data collection instrument in this study. The main questions asked during interview session included the educational background and experience of the participants in the area of financial management, the strategies used by the participants for effective financial management, the main strategies the participants use to manage the finance of their schools, the sources of the finances the schools receive, and the challenges and difficulties they encounter during the implementation of the financial management. Guided questioning was also used by the researcher during the interview to encourage the participants' more explanations and elaborations on the topic wherever needed, and therefore gain more information and eliminate the ambiguities.

The questions raised in the interview session were as follows: 
1. In your school who is/are responsible for the financial management, except you?

2. What are the sources of funding for your school? Where do you get the school funding from?

3. What do you think strategic financial management stands for? What strategies do you use for school financial management?

4. What challenges and difficulties do you face in the process of school financial management?

5. How do you prioritize the school budget?

6. Have you received financial training before taking this responsibility?

7. Does the school report about the annual school budget and its way of spending to parents or any related organization?

8. Does the school budget suffice the school needs?

9. Does the school has a safety room or specific office place for keeping and managing the school funds?

10. As a responsible person in this case, do you keep a record of school expenses?

11. What do you do to raise school funds?

\section{Procedure}

The participants were interviewed by the researcher in different days. During the interview sessions, the researcher asked the questions which were designed in advance and tried to elicit more information from the participants' responses and clarify their responses to the interview questions, whenever needed.

It must be asserted that ethical issues where considered during the administration of the interview sessions, and the confidentiality of data were guaranteed. 


\section{Data Analysis and Results}

Considering the interview results, the qualitative analysis had been conducted. Using open-coding strategy, the data were reduced to manageable patterns and themes and these patterns were identified and reported.

According to the participants' responses to each of the questions raised in the interview sessions, we came up with the following results and findings:

Participants' responses to the question $\neq \mathbf{1}$ (In your school who is/are responsible for the financial management, except you?)

Approximately all of the participants claimed that they were the main person responsible for the school financial management, while few of these schools $(n=3)$ hired accountants to help them in the management of the funds and expenses. In this respect one of the participants explained that:

"...basically, as we can see in developed countries, the schools must have accountants officially hired by the education ministry, while unfortunately here most of the school responsibilities are on the back of headmasters including financial management which is a very important job."

Accordingly, another participants also elaborated that:

“...the government doesn't hire accountants for the schools and doesn't pay for them if the schools hire them by themselves, because they consider our schools not big enough to need it. Therefore it is considered the responsibility of the school principals only. But some big schools with large number of students, use the school budgets to hire accountants or skilled people to help them in managing the budget and the financial issues. But even in this case, still the principal remains as the main person responsible for this work."

It must be noted that the three school principals which used the help of accountants in their process of financial management, declared that the accountants they hired 


\section{QALAAI ZANISTSCIENTIFIC JOURNAL \\ A Scientific Quarterly Refereed Journal Issued by Lebanese French University - Erbil, Kurdistan, Iraq \\ Vol. (5), No (4), Winter 2020 \\ ISSN 2518-6566 (Online) - ISSN 2518-6558 (Print)}

were paid for one or two days of work for each month, not receiving a full salary. That is because they only checked and worked on the financial documents and affairs done by the school principals at the end of each month, not having a full time job.

Participants' responses to the question $\neq 2$ (What are the sources of funding for your school? Where do you get the school funding from?)

All participants considered government as the main source of funding in the first place (although as it will be discussed later, the budget they allocate is very low). The other sources mentioned by the participants based on the frequency of statement were parents' collaboration in helping school financially (91.6\%), school fund raising activities (75\%), financial assistance from outside donors (58.3\%), and financial support from specific organizations and production companies (16.6\%).

Participants' responses to the question $\neq 3$ (What do you think strategic financial management stands for? what strategies do you use for school financial management?)

Majority of the participants (91.6\%) considered setting goal and making decisions and planning for the present time and future of the finances and their management based on those specific goals as the integral part of strategic financial management. One participant defined it as :

"it stands for considering all school resources, conditions, needs and goals, and then setting a plan for how to run the school based on them in terms of how to spend and manage the finances in the future."

Similarly, another one defined it as:

“...managing the school budget by strategically planning how to spend them in future based on what is needed like educational instruments, facilities, and like that, and based on what are our aims of planning for the school budget and how we are going to raise the school funds." 
Considering the strategies they use for school financial management, surprisingly all of the participants referred to collecting data on the school needs, students' needs, the overall situation of the school and its properties, and the amount of budget and finances, and in general the present situation, conditions and needs of the school, staff and students, and the present and future needs and expectations, as the most important strategies for an effective financial management. Half of the participants also referred to the importance of providing short time plans like 2-3 years of financial plans, so that they can be more manageable and have more chance of becoming successful.

Participants' responses to the question $\neq 4$ (What challenges and difficulties do you face in the process of school financial management?)

The main and the most important challenges that the participants faced in this regard, as all of them mentioned was the high number of school deficiencies, needs and requirements while having the insufficient school budget and inadequate school funding. Interestingly all of them complained about the government and education ministry for allocating very low school funding while their needs are much more.

The other challenges and difficulties based on the frequency of the participants' responses are as follows:

- Donations received by school from parents are very low, and the parents usually do not cooperate well in this respect $(75 \%)$.

-Finding out-of-school donors is a very hard job (58.3\%)

Participants' responses to the question $\neq 5$ (How do you prioritize the school budget?)

Most of the participants (91.6\%) declared that the first thing they do with their budget is to pay the bills (e.g. electricity). 


\section{QALAAI ZANISTSCIENTIFIC JOURNAL \\ A Scientific Quarterly Refereed Journal Issued by Lebanese French University - Erbil, Kurdistan, Iraq \\ Vol. (5), No (4), Winter 2020 \\ ISSN 2518-6566 (Online) - ISSN 2518-6558 (Print)}

The other most frequently stated priorities include equipping the school (83.3\%), paying for maintenance, repairs, and construction (75\%), and educational affairs (75\%) respectively.

Participants' responses to the question $\neq 6$ (Have you received financial training before taking this responsibility?)

$83.3 \%$ of the participants reported that they had received financial training. However, $60 \%$ of them were trained before taking this responsibility as one of their university courses and $40 \%$ of them were trained after taking this responsibility during in-service teacher training courses they had passed. The rest of the participants (16.6\%) reported that they had learned it by self-study and gaining experience.

Considering this issue, the participants in general were not satisfied with the quality of financial management trainings they had received and they didn't consider them enough for making them successful in this respect, as one of the participants stated that:

"....during our teacher training courses, this specific course were not paid enough attention and being thought as a serious and important skill, and it was long time ago. If you ask me, I tell you that I don't remember about that course. Just few practical points. The system we were taught with, was old. I think I still need to learn about it. That is why we need help from an accountant, for I most of the time think something is wrong."

Participants' responses to the question $\neq 7$ (Does the school report about the annual school budget and its way of spending to parents or any related organization?)

All the participants declared that the report on financial issues including the school budget, and details about the expenses are reported to both education department of the education ministry at their own city and to the Parent-Teacher Association.

Participants' responses to the question $\neq \mathbf{8}$ (Does the school budget suffice the school needs?) 


\section{QALAAI ZANISTSCIENTIFIC JOURNAL \\ A Scientific Quarterly Refereed Journal Issued by Lebanese French University - Erbil, Kurdistan, Iraq \\ Vol. (5), No (4), Winter 2020 \\ ISSN 2518-6566 (Online) - ISSN 2518-6558 (Print)}

Interestingly, none of the participants considered the school budget, enough for fulfilling the school's financial needs, specially the fund they receive from the government

Participants' responses to the question $\neq \mathbf{9}$ (Does the school has a safety room or specific office place for keeping and managing the school funds?)

Nearly all participants $(n=11)$ declared that their schools lack of safety room or specific place for keeping the financial documents and the related works. However, the other participant stated that the school has a specific room for the financial affairs, as he said:

"Yes, in our school we have a small room which is allocated for the works including financial affairs, though other works are done there too. For example in specific days, that room is used for different works including paper correction and filing".

Moreover, all the participants declared that they do not keep any cash at school and all the school budget are kept in the school's bank deposit, so that they prevent any probable problem in this case.

Participants' responses to the question $\neq 10$ (As a responsible person in this case, do you keep a record of school expenses?)

All the participants declared that they keep the record of all school expenses along with the funds they receive, mainly because they were supposed to provide a financial report for both education department and parent-teacher association.

Participants' responses to the question $\neq \mathbf{1 1}$ (What do you do to raise school funds?)

The participants answered this question almost similarly. All the participants reported that they use out-of-school donors and parents' financial support. Majority of them (91.6\%) reported that they use fund raising activities, such as holding extracurricular classes for the students and use part of the tuition they get from the students for the school needs.16.6\% of the participants reported for using charity bazaar, where the 
students sell things like their handmade and save money for school that way.58.3\% of the participants declared that they ask other related organizations or companies which are willing to be sponsor to financially assist and support the school.

\section{Recommendation:}

1- The Ministry of Education has to hire accountants for schools to help them in the management of the funds and expenses.

2-managing budget and financial issue have to be on back of accountant.

3- Finding a way to increase donations received by school from parents.

4-increasing modern teachers' training courses.

5-Allocate a big room for the works including financial affairs.

\section{Discussion and Conclusion}

As the findings of this study revealed, majority of the participants have almost similar understanding of financial management and strategic management of finances which represent that theoretically they are well- informed about the nature of this issue. However, they mostly complained about the insufficient school funding by the government and the low quality of financial management training in general and strategic financial management training in particular during their teacher training courses, which must be considered by the education system. Moreover, the difficulties and challenges that the participants proposed in implementing financial management, are important to be considered and resolved by the education system to improve the level of strategic financial management in the schools of Kurdistan region of Iraq.

This study is useful and beneficial for all school principals, head masters, and education system policy makers. 


\section{QALAAI ZANISTSCIENTIFIC JOURNAL \\ A Scientific Quarterly Refereed Journal Issued by Lebanese French University - Erbil, Kurdistan, Iraq \\ Vol. (5), No (4), Winter 2020 \\ ISSN 2518-6566 (Online) - ISSN 2518-6558 (Print)}

\section{References:}

Brent, B.O., \& Finnigan, K.S. (2009) Financial Management of New York's Charter Schools: A Normative, Descriptive, and Prescriptive Analysis, Journal of School Choice, 3:4, 368396, DOI: $10.1080 / 15582150903425772$.

Delkhosh,M., \& Mousavi, H. (2016). Strategic Financial Management Review on the Financial Success of an Organization. Mediterranean Journal of Social Sciences, 7(2),30-34.

Karadag, H. (2015). Financial management challenges in small and medium-sized enterprises: A strategic management approach. Emerging Markets Journal, 5(1), 26-40. doi:10.5195/emaj.2015.67

Mpolokeng, T,E. (2011). The Effectiveness of Financial Management in Schools in the Lejweleputswa Education District. Unpublished MA thesis. Central University of Technology, Free StateWelkom Campus, South Africa.

Okafor, R. G. (2012). Financial management practices of small firms in Nigeria: Emerging tasks for the accountant. European Journal of Business and Management, 4(19), 159-169. Retrieved from http://www.iiste.org/Journals/index.php/EJBM

Owen, J.O. (2006). How to manage. London: Pearson Education Limited.

Oosthuizen, I.J. \& Botha, P. (2002). Aspects of education law. 3rd Ed. Pretoria: Van Schaik.

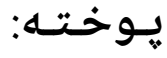

تواناى بهريّوهبردنى دارايى ستراتيزى ، وهك يهكيك له كليلى تواناى بهرزكردنهوه و جوله ى كليلييه كانى كهشهييّدانه ، بابهتيّكه كه ههميشه لهلايهن يسيوّران و جيّبه جيّكارانهوه يهسهند كراوه ، له گهل ئهوهشدا له ميّزه له بوارى يهروهردهدا يشتگوى خراوه ـ به لهبهرجاوگرتنى گرنكى ئهم بابهته له بوارى يهروهردهدا ، ئهم لِيكوَلِينهوهيه به مهبهستى لِيكوَليّنهوه له رِاى بهريّوهبهرى قوتابخانهكان بهرامبهر بهو جوّره بهريّوهبردنه و جيّبه جيّكردنى له قوتابخانهكانى ههيِمى كوردستانى عيّراق . لهم 


\section{QALAAI ZANISTSCIENTIFIC JOURNAL}

A Scientific Quarterly Refereed Journal Issued by Lebanese French University - Erbil, Kurdistan, Iraq

Vol. (5), No (4), Winter 2020

ISSN 2518-6566 (Online) - ISSN 2518-6558 (Print)

رِوهوه 12 بهرِيوهبهرى ئامادهيى لهو جوارجِيوهيهدا وهك بهشداربوانى ئهم لِيّكوّلِينهوهيه دهستنيشان

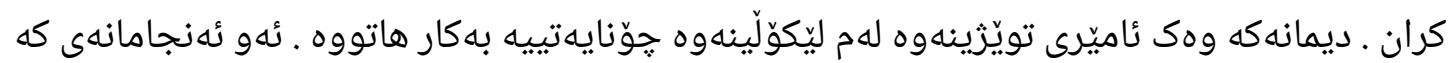
لهبهشى ئهنجامهكاندا ورددهبنهوه ، دهريخست كهسيستمى خويّندن زوّر بهخرايى كارى كردووه لهيهرهييّدان و يِيشخستنى بهريّوهبهرايهتيى دارايى لهكوردستاندا ، يِيويسته ههولّيش بدات مهشقى

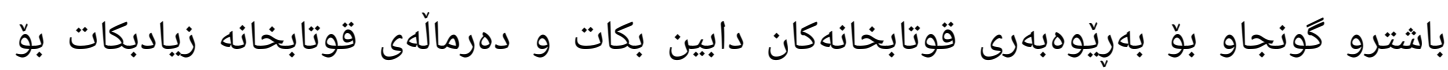
يارمهتيدانى بهريّوهبهرى قوتابخانهكان بوّ لابردنى ئهو كيشهو گرفت انهى كه لهو بوارهدا رووبهرِوويان دهبيّتهوه .

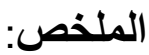

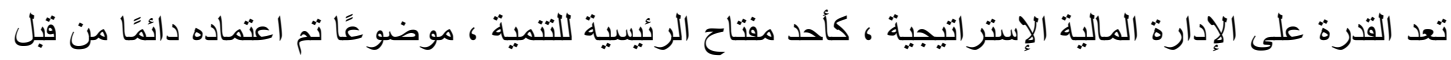

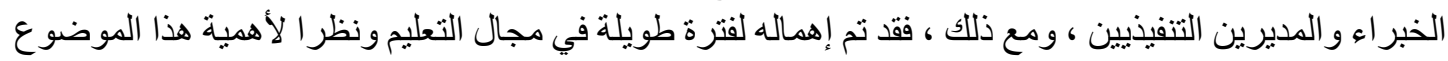

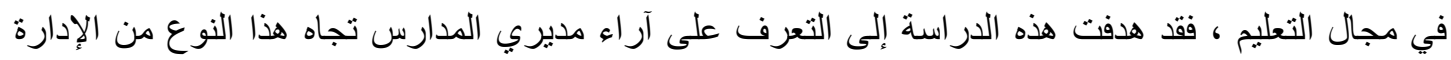

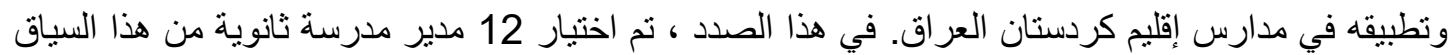

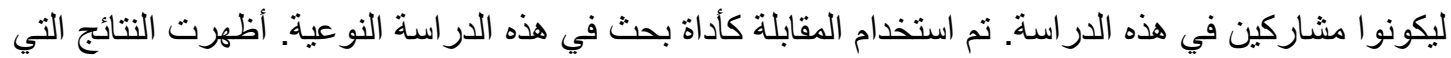

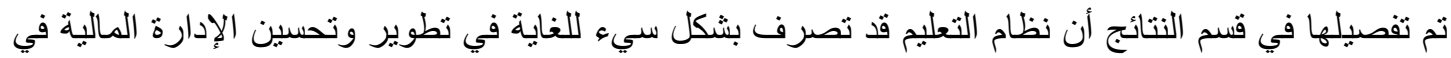

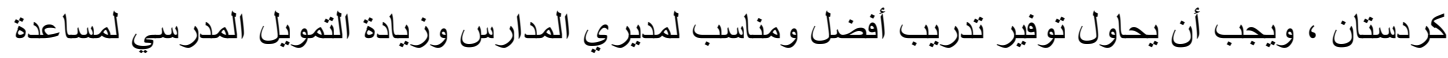

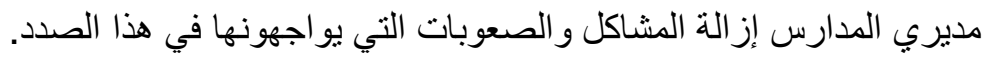

